JGRADASI TEKnIK SIPIL 


\section{JURNAL GRADASI TEKNIK SIPIL POLITEKNIK NEGERI BANJARMASIN}

Jurnal Gradasi Teknik Sipil diterbitkan oleh Pusat Penelitian dan Pengabdian Kepada Masyarakat Politeknik Negeri Banjarmasin. Ruang lingkup makalah meliputi Bidang Teknik dan Manajemen dengan konsentrasi Bidang Transportasi, Geoteknik, Struktur, Keairan dan Manajemen Konstruksi. Isi makalah dapat berupa penyajian isu aktual di bidang Teknik Sipil, review terhadap perkembangan penelitian, pemaparan hasil penelitian, dan pengembangan metode, aplikasi, dan prosedur di bidang Teknik Sipil. Makalah ditulis mengikuti panduan penulisan.

\section{Penanggung Jawab}

Nurmahaludin, ST, MT.

\section{Dewan Redaksi}

Ketua :

Anggota : Riska Hawinuti, ST, MT.

Nurfitriah, S.Pd, MA.

Ir. Rusliansyah, M.Sc.

\section{Reviewer}

Dr. Ir. Yanuar Jarwadi Purwanto, MS. (Institut Pertanian Bogor)

Dr. Ir. Achmad Rusdiansyah, MT. (Universitas Lambung Mangkurat)

Dr. Ir. M. Azhar, M. Sc. (Institut Sains dan Teknologi Nasional)

Dr. Ir. Endang Widjajanti, MT. (Institut Sains dan Teknologi Nasional)

Joni Irawan, ST, MT. (Politeknik Negeri Banjarmasin)

Yusti Yudiawati, ST, MT. (Politeknik Negeri Banjarmasin)

\section{Editing dan Tata Bahasa}

Nurfitriah, S.Pd., MA.

\section{Desain dan Tata Letak}

Abdul Hafizh Ihsani

\section{Alamat Redaksi}

Jurusan Gradasi Teknik Sipil Politeknik Negeri Banjarmasin, Jl. Brigjen H. Hasan Basri 70123 Banjarmasin Telp/Fax 0511-3307757; Email: gradasi.tekniksipil@poliban.ac.id 


\section{JURNAL GRADASI TEKNIK SIPIL}

\section{DAFTAR ISI}

Perencanaan Campuran Lapis Aspal Beton Permukaan Dengan Asbuton Butir Sebagai Filler ...( 1 - 9 )

Surat, Rifanie Gazalie, Pazilatul Mumamiroh

Pengaruh Keberadaan Pasar Sungai Lulut Terhadap Kinerja Jalan Martapura Lama KM. 05 ...( 10 - 19)

\section{Riska Hawinuti}

Analisis Perbandingan Biaya Penggunaan Perancah Kayu Galam Dan Perancah Besi (Scaffolding) ...( $20-32)$ Aunur Rafik, Rinova Firman Cahyani

Tinjauan Debit Andalan untuk Irigasi di Kecamatan Sungai Tabuk Kabupaten Banjar ...( $33-43)$

Fakhrurrazi, Herliyani Farial Agoes, Desi Anggeriyani

Ekosemen Sebagai Media Perekat Pengganti Semen Untuk Beton ...( 44 - 51 ) Marhadi Sastra, Juli Ardita Pribadi R

Pengaruh Posisi, Jumlah Layer Dan Mutu Kayu Terhadap Balok Laminasi Kayu Mahang Dan Kayu Meranti ...( 52 - 60 )

\section{Indriyani Puluhulawa}

Visualisasi Dan Identifikasi Pola Retak Dinding Bata Akibat Penurunan Pondasi Struktur Bangunan Di Kota Banjarmasin ...( 61 - 68 )

\section{Darmansyah Tjitradi, Eliatun}

Pengembangan Perumahan Dengan Desain Konstruksi Dilahan Basah Pada Wilayah Kota Banjarmasin Menggunakan Riset Operasi ...( 69 - 75 )

\section{Eliatun, Darmansyah Tjitradi}




\title{
Tinjauan Debit Andalan untuk Irigasi di Kecamatan Sungai Tabuk Kabupaten Banjar
}

\author{
Fakhrurrazi $^{1 *}$, Herliyani Farial Agoes ${ }^{2}$, Desi Anggeriyani ${ }^{3}$ \\ ${ }^{1,2}$ Dosen Jurusan Teknik Sipil Politeknik Negeri Banjarmasin \\ ${ }^{3}$ Mahasiswa Jurusan Teknik Sipil Prodi Teknik Bangunan Rawa \\ e-mail: *'fakhrurrazi@poliban.ac.id (corresponding author), ${ }^{2}$ hfagoes@poliban.ac.id
}

\begin{abstract}
Abstrak
Ketersediaan air yang memadai pada sistem irigasi merupakan faktor penting dalam keberhasilan pertanian irigasi, termasuk sistem irigasi Sungai Tabuk yang produktif ditanami oleh padi sawah, padi ladang serta palawija. Ketersediaan air di Kecamatan Sungai Tabuk dihitung dengan analisis debit andalan menggunakan data debit hasil perhitungan metode Mock. Model hubungan hujan-debit dengan interval bulanan yang digunakan adalah metode Mock, dan dilakukan perhitungan debit andalan 80\% untuk menghitung ketersediaan air irigasi..Berdasarkan data bangkitan hujan dan evapotranspirasi (metode Mock) didapat pada sistem irigasi wilayah Sungai Tabuk debit rata - rata pertahun adalah 5,758 $\mathrm{m3}$ / detik. Dengan debit tertinggi terjadi pada bulan Maret yaitu 9,405m3/ detik dan debit terendah berada pada bulan September sebesar 1,616 m3 / detik. Debit andalan $80 \%$ didapat rata - rata adalah 3,504 m3/ detik dengan debit andalan $80 \%$ tertinggi tedapat pada bulan Februari yaitu 7,37 m3/ detik dan debit terendah berada pada bulan Oktober yang debit 80\% nya didapat 0,24 m3/ detik. Adapun untuk perhitungan kebutuhan air irigasi berdasarkan KP-01. Dari hasil perhitungan didapat kebutuhan air rata-rata adalah 2,690 m3/detik dimana awal tanam Desember I dengan menggunakan pola tanam padi biasa-padi biasa, sedangkan kebutuhan air untuk palawija rata-rata adalah 0,029 m3/detik. Dari hasil analisa didapat ketersediaan air saluran irigasi Sungai Tabuk (nilai rata-rata 3,504 m3/detik) bisa memenuhi kebutuhan air irigasi (nilai rata-rata 2,690 +0,029 = 2,719 $\mathrm{m} 3 /$ detik).
\end{abstract}

Kata kunci-Debit Andalan, Metode Mock, Sungai Tabuk.

\begin{abstract}
Adequate water availability in irrigation systems is an important factor in the success of irrigation agriculture, including Sungai Tabuk irrigation system which land is planted with rice paddy, fields rice paddy and crops. The availability of water in Kecamatan Tabuk River was calculated by dependable flow analysis using flow data from Mock method calculation. The model of rainfall-flow relationship with the monthly interval used was Mock Method, and $80 \%$ dependable flow was used to calculate the availability of the irrigation water. Based on the rainfall and evapotranspiration data (Mock method) in irrigation system of Sungai Tabuk area, the average flow per year of $5.758 \mathrm{~m} 3$ / sec obtained. With the highest flow occurred in March of $9.405 \mathrm{~m} 3$ / sec and the lowest flow was in September at $1.616 \mathrm{~m} 3$ / sec. The $80 \%$ dependable flow was an average of $3.504 \mathrm{~m} 3$ / sec with the highest 80\% of the highest dependable flow recorded in February of $7.37 \mathrm{m3} / \mathrm{sec}$ and the lowest flow was in October which $80 \%$ flow was $0.24 \mathrm{m3} / \mathrm{sec}$. The calculation of irrigation water needed was based on KP-01. The calculation results showed that the average water demand was $2.690 \mathrm{~m} 3 / \mathrm{sec}$ with the beginning of planting on December I by using ordinary rice-ordinary rice planting pattern; while the average water demand for crops was $0.029 \mathrm{~m} 3$ / sec. From the analysis, the availability of irrigation water of Sungai Tabuk (average value of 3,504 $\mathrm{m} 3 / \mathrm{sec}$ ) can fulfil the irrigation water requirement (average value of $2,690+0,029=2,719 \mathrm{m3} / \mathrm{second}$ ).
\end{abstract}

Keywords—Debit Andalan, Metode Mock, Sungai Tabuk. 


\section{PENDAHULUAN}

Sumber daya air dari suatu sungai sangatlah beragam, terutama untuk sektor pertanian, perikanan dan PLTA. Pada sektor pertanian, pemakaian air baku untuk mengairi sawah merupakan faktor keberhasilan pada sektor pangan melalui sistem irigasi. Sistem Irigasi merupakan faktor penting dalam keberhasilan pertanian irigasi. Jaringan irigasi merupakan sarana untuk mengalirkan air ke persawahan, air yang dialirkan tentulah yang telah dihitung kecukupannya untuk areal yang akan diairi. Ketersediaan air Irigasi untuk pertanian ini perlu dihitung untuk memenuhi kebutuhan air disawah.

Sungai Tabuk merupakan potensi yang cukup besar sebagai lahan produktif yang dapat dikembangkan lewat pengelolaan saluran irigasi, salah satu bagian dalam mengembangkan lahan itu sendiri perlu dilakukan perhitungan ketersediaan air dengan menggunakan analisis debit andalan. Debit andalan merupakan debit yang kemungkinan terjadinya sama atau melampaui dari yang diharapkan pada daerah tersebut serta untuk memenuhi kebutuhan air di lahan persawahan .Pada sistem irigasi Sungai Tabuk pada lahan yang produktif ditanami oleh padi sawah, padi ladang serta palawija. Untuk hasil panen yang bagus maka harus diberi pemberian air untuk memenuhi kebutuhan air yang disuplai untuk tanaman agar tumbuh. Besarnya suplai tanaman tentu saja menyebabkan harus adanya ketersediaan air pada Kecamatan Sungai Tabuk.

Ketersediaan air itu didapat dengan analisis Debit andalan $80 \%$, metode debit andalan memerlukan input data debit aliran Sungai Tabuk yang bisa didapat secara langsung maupun tidak langsung, secara langsung dapat dilakukan setiap jam dalam sehari selama minimal 10 tahun, bila data secara langsung tidak didapat maka data debit diperoleh dengan data curah hujan dan evapotranspirasi. Untuk menghitung evapotranspirasi perlu data klimatologi (temperatur, penyinaran matahari, kecepatan angin, dan kelembaban relatif ) dan posisi lintang pada lokasi penelitian (Kecamatan
Sungai Tabuk), dengan menggunakan data hujan dan klimatologi nantinya akan menghasilkan data aliran debit sungai pada Kecamatan Sungai Tabuk sehingga data aliran sungai ini akan menjadi data untuk memproses Debit Andalan 80\% ketersediaan air pada sistem irigasi kecamatan Sungai Tabuk. Sebagai upaya pemenuhan kebutuhan air untuk pertanian perlu diketahui kondisi aliran saluran irigasi di Kecamatan Sungai Tabuk dengan menghitung debit aliran yang ada agar dapat diketahui berapa besar ketersediaan air di Kecamatan Sungai Tabuk.

Penelitian tentang ketersediaan air tahun 2015 menyatakan Debit Sungai Talawaan tidak cukup mengairi seluruh petak tersier dengan sistem pengairan secara terus menerus. Dicoba untuk membuat variasi pola tanam dan mengubah koefisien rotasi petak tersier. Dari 9 pola tanam yang dicoba yang paling optimal adalah pola tanam 9 dengan variasi 1 musim tanam, 3 golongan dan koefisien rotasi $=0,5$. (Viralsia Ivana Kundimang, Liani A. H., Eveline M.W., 2015). Analisis Keseimbangan Air DAS Tabanio Kab. Tanah Laut memberikan gambaran hasilsetelah dilakukan pengukuran debit dilapangan, ternyata data debit metode Mock sangat mendekati dengan data debit dilapangan (Sungai Tabanio). Sehingga dalam analisis keseimbangan air di DAS Tabanio, ketersediaan air/debit andalan yang akan digunakan adalah debit andalan menggunakan data debit metode Mock.(Agoes Herliyani Farial, Fakhrurrazi, Muhlis Adriani ,2014)

Ketersediaan air menunjukkan indikator daya dukung air bagi lingkungan hidup terutama bagi penduduk dan kehidupannya. Ketersediaan air tidak merata sepanjang tahun, sehingga di suatu tempat sering dijumpai kesulitan mendapatkan air pada musim kemarau dan kelebihan air pada musim penghujan.Sumber daya air yang akan dianalisa di wilayah ini adalah air permukaan/sungai. Untuk menganalisa ketersediaan air dilakukan perhitungan debit andalan.

Debit andalan merupakan debit yang kemungkinan terjadinya sama atau dilampaui dari yang diharapkan. Debit andalan yang dimaksudkan 
disini adalah debit yang mengalir pada suatu penampang sungai dalam suatu daerah pengaliran sungai (DPS). Berikut adalah beberapa nilai probabilitas yang diandalkan dalam beberapa perencanaan teknik sumber daya air (Soemarto 1995).

a. Penyediaan air minum (PDAM) : 99\%.

b. Pembangkit listrik tenaga air (PLTA) : 85\% $-90 \%$.

c. Penyediaan air industri : $88 \%-95 \%$.

d. Penyediaan air irigasi

- Daerah beriklim setengah lembab : 70\% $85 \%$.

- Daerah beriklim terang : 80\% - 95\%.

Metode Mock dikembangkan oleh F.J. Mock (Mock, 1973) berdasarkan atas daur hidrologi.Metode Mock merupakan salah satu dari Metode yang menjelaskan hubungan rainfallrunoff.

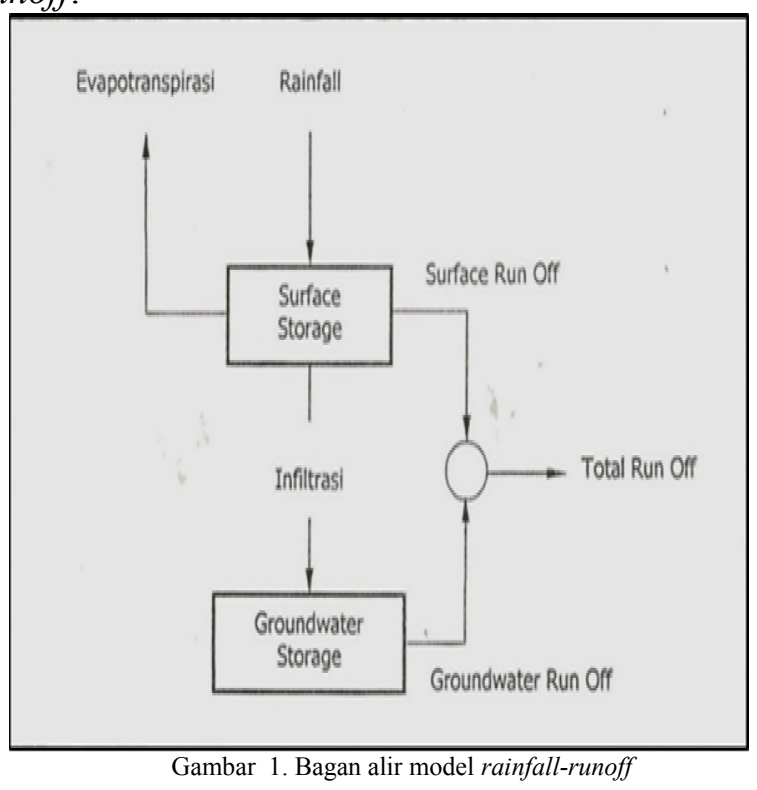

Metode Mock dikembangkan untuk menghitung debit bulanan rata-rata. Data-data yang dibutuhkan dalam perhitungan debit dengan metode Mock ini adalah data klimatologi, luas dan penggunaan lahan dari catchment area. Proses perhitungan yang dilakukan dalam metode Mock dijelaskan dalam Gambar 2 berikut.

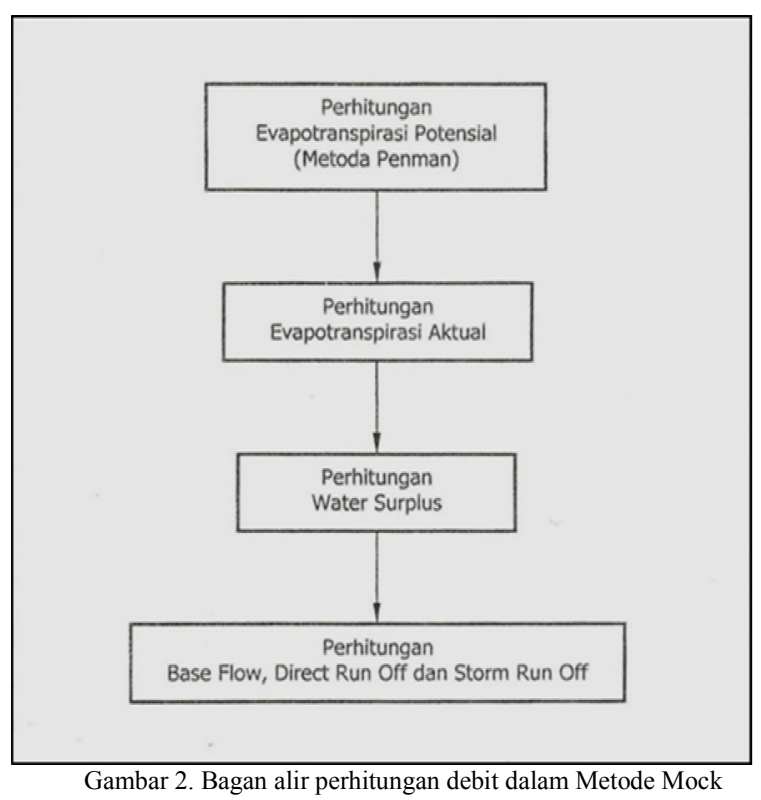

Ketersediaan air menunjukkan indikator daya dukung air bagi lingkungan hidup terutama bagi penduduk dan kehidupannya. Ketersediaan air tidak merata sepanjang tahun, sehingga di suatu tempat sering dijumpai kesulitan mendapatkan air pada musim kemarau dan kelebihan air pada musim penghujan. Dari analisa debit andalan, didapat ratarata ketersedian air irigasi. Kebutuhan air irigasi dilakukan perhitungannya berdasarkan perencanaan irigasi KP-01, sehingga didapat besarnya rata-rata kebutuhan air disawah. Dari hasil analisis, nanti didapat apakah ketersediaan air dapat memenuhi kebutuhan air irigasi atau tidak.

\section{METODE PENELITIAN}

Lokasi penelitian termasuk dalam wilayah Kecamatan Sungai Tabuk, Kabupaten Banjar , Propinsi Kalimantan Selatan. Pemantauan langsung ke lapangan dilakukan terhadap daerah aliran saluran irigasi di Kecamatan Sungai Tabuk yaitu lahan pertanian dan aliran saluran irigasi di daerah tersebut. Data sekunder yang diperlukan untuk penelitian ini antara lain: (1) curah hujan harian sepuluh tahunan pada sekitar daerah irigasi Sungai Tabuk, data ini didapat dari Dinas BP3K Landasan Ulin, Dinas BP3K Lingkar Selatan dan SMPK Sungai Tabuk ( masing-masing per 10 tahun ); (2) data klimatologi dari stasiun hujan di SMPK Sungai 
Tabuk; dan (3) luas daerah dan luas irigasi di Kecamatan Sungai Tabuk, diperoleh dari Kantor Kecamatan Sungai Tabuk.

Analisa data meliputi :

1. Analisa data klimatologi dan hujan

2. Data klimatologi (temperatur, penyinaran matahari, kecepatan angin, dan kelembaban relatif) yang digunakan adalah dari pos klimatologi Sungai Tabuk, sedangkan data curah hujan harian berasal dari 3 stasiun curah hujan, yaitu Stasiun Sungai Tabuk, Stasiun Landasan Ulin, dan Stasiun Lingkar Selatan Kabupaten Banjar.

3. Analisa kebutuhan air di sawah berdasarkan KP-01.

4. Analisa ketersediaan air / Debit Andalan $80 \%$ dengan menggunakan data debit hasil metode Mock.

5. Analisa keseimbangan air pada irigasi Sungai Tabuk.

\section{HASIL DAN PEMBAHASAN}

Kabupaten Banjar merupakan salah satu lumbung padi di Kalimantan Selatan. Luas lahan pertanian di Kabupaten Banjar sebesar 60.000 Ha dengan luas lahan abadi sebesar 15.000 Ha. Kabupaten Banjar yang ber-ibu kota Martapura daerahnya dilintasi oleh sungai besar yaitu sungai Martapura. Sungai ini menghubungkan kota Martapura dengan Banjarmasin, kemudian muaranya bersatu dengan sungai Barito. Batas wilayah Kabupaten Banjar meliputi: sebelah utara berbatasan dengan Kabupaten Tapin, sebelah selatan berbatasan dengan Kota Banjarbaru dan Kabupaten Tanah Laut, sebelah timur berbatasan dengan Kabupaten Kotabaru dan Tanah Bumbu dan sebelah barat berbatasan dengan Kota Banjarmasin dan Kabupaten Barito Kuala. Kabupaten Banjar berada di antara 2\%49'55 - 3'43'38 Lintang Selatan dan diantara $114^{\circ} 30^{\prime} 20^{\prime \prime}$ - 115'35'37" Bujur Timur. Luas Wilayah Kabupaten Banjar adalah \pm 4.688 $\mathrm{km} 2$.

Dengan jumlah penduduk 489.056 orang yang terdiri dari 240.823 laki - laki dan 248.233 perempuan, jumlah penduduk terbanyak berada di Kecamatan Martapura dengan kepadatan 2.078 penduduk per km2. Sebagaimana diketahui wilayah
Kabupaten Banjar dilintasi oleh sungai besar yaitu sungai Martapura. Kondisi topografinya beraneka ragam, tidak sepenuhnya dataran, perbukitan dan pegunungan. Keadaan hidrografinya dipengaruhi oleh curah hujan, terlebih lagi daerah rawa. Sungai Tabuk meliputi satu kelurahan dan 20 desa. Luas Sungai Tabuk 147,30 km2 atau sekitar satu setengah kali luas kota Banjarmasin. Pada tahun

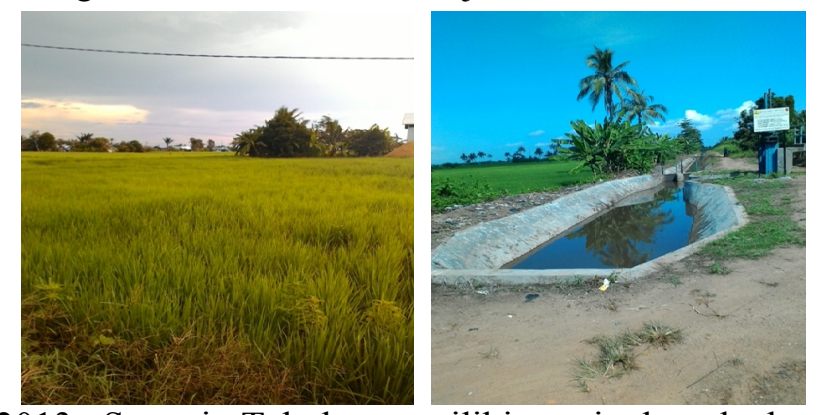

2013 Sungai Tabuk memiliki peringkat kedua sebagai kecamatan dengan jumlah penduduk paling banyak di Kabupaten Banjar.

Gambar 3. Kondisi Persawahan dan Irigasi Sungai Tabuk

\section{Klimatologi}

Data klimatologi yang digunakan berasal dari stasiun SMPK Sungai Tabuk. Sedangkan data curah hujan berasal dari 3 stasiun curah hujan yaitu : SMPK Sungai Tabuk, BP3K Landasan Ulin, dan BP3K Lingkar Selatan. Data Klimatologi yang tercatat pada stasiun SMPK Sungai Tabuk adalah temperatur udara, penyinaran matahari, kecepatan angin, dan kelembaban relatif.

\section{Temperatur Udara}

Berdasarkan data klimatologi yang tercatat pada stasiun SMPK Sungai Tabuk, temperatur udara di Kecamatan Sungai Tabuk yang tercatat pada tahun 1997 - 2006 menunjukkan bahwa temperatur udara rata-rata di Kecamatan Sungai Tabuk adalah $28,10{ }^{\circ} \mathrm{C}$. Temperatur udara rata-rata tertinggi $28,80{ }^{\circ} \mathrm{C}$ pada bulan Mei dan temperatur rata-rata terendah $27,70{ }^{\circ} \mathrm{C}$ pada bulan September .

Kelembaban Relatif

Berdasarkan data klimatologi yang tercatat pada stasiun SMPK Sungai Tabuk, kelembaban di 
Kecamatan Sungai Tabuk yang tercatat pada tahun 1997 - 2006 menunjukkan bahwa kelembaban ratarata di Kecamatan Sungai Tabuk adalah 82,6\%. Kelembaban rata-rata tertinggi $85,10 \%$ pada bulan Desember dan kelembaban rata-rata terendah $77,60 \%$ pada bulan September.

Kecerahan Matahari/Lama Penyinaran Matahari

Berdasarkan klimatologi yang tercatat pada Stasiun SMPK Sungai Tabuk, penyinaran matahari di Kecamatan Sungai Tabuk yang tercatat pada tahun 1997 - 2006 menunjukkan bahwa penyinaran matahari rata-rata di Kecamatan Sungai Tabuk adalah $41,50 \%$. Penyinaran matahari rata-rata tertinggi $54,50 \%$ pada bulan Juli dan penyinaran matahari rata-rata terendah $29,50 \%$ pada bulan Desember.

Kecepatan Angin

Berdasarkan klimatologi yang tercatat pada Stasiun SMPK Sungai Tabuk Kecepatan angin di Kecamatan Sungai Tabuk yang tercatat pada tahun 1997 - 2006 menunjukkan bahwa kecepatan angin rata-rata di Kecamatan Sungai Tabuk adalah 19,50

Tabel 1. Perhitungan Uji Data Hujan Pasangan Stasiun Hujan Lingkar Selatan-Sungai Tabuk

\begin{tabular}{|c|c|c|c|c|c|c|c|}
\hline No. & Tahun & lingkar selatan & $\left(X_{i}-X^{-}\right)$ & $\left(X_{i}-X^{-}\right)^{2}$ & sungai tabuk & $\left(X_{i}-X^{-}\right)$ & $\left(X_{i}-X^{-}\right)^{2}$ \\
\hline 1 & 2006 & 1576.0 & -120.3 & 14467.3 & 1798.7 & -566.1 & 320508.8 \\
\hline 2 & 2007 & 1682.6 & -13.7 & 187.1 & 2796.5 & 431.7 & 186377.8 \\
\hline 3 & 2008 & 1277.0 & -419.3 & 175795.7 & 2526.0 & 161.2 & 25990.3 \\
\hline 4 & 2009 & 1095.5 & -600.8 & 360936.6 & 2269.7 & -95.1 & 9041.2 \\
\hline 5 & 2010 & 1496.5 & -199.8 & 39912.0 & 3539.8 & 1175.0 & 1380660.3 \\
\hline 6 & 2011 & 1574.0 & -122.3 & 14952.4 & 2343.5 & -21.3 & 453.1 \\
\hline 7 & 2012 & 1510.0 & -186.3 & 34700.2 & 2170.1 & -194.7 & 37902.2 \\
\hline 8 & 2013 & 2437.5 & 741.2 & 549407.1 & 2064.7 & -300.1 & 90051.0 \\
\hline 9 & 2014 & 2439.7 & 743.4 & 552673.3 & 1941.2 & -423.6 & 179424.3 \\
\hline 10 & 2015 & 1874.0 & 177.7 & 31584.4 & 2197.7 & -167.1 & 27917.4 \\
\hline umlah ¿Xi & 16962.8 & 0.0 & 1774616.2 & 23647.9 & 0.0 & 2258326.3 \\
\hline tta-RataX & 1696.3 & & & 2364.8 & & \\
\hline
\end{tabular}

$\mathrm{km} / \mathrm{hari}$. Kecepatan angin rata-rata tertinggi 29,28 $\mathrm{km} / \mathrm{hari}$ pada bulan Desember dan kecepatan angin rata-rata terendah $11,85 \mathrm{~km} /$ hari pada bulan Juni.

Data Curah Hujan

Terdapat 3 stasiun hujan yang berada disekitar irigasi Sungai Tabuk, yaitu Stasiun SMPK Sungai Tabuk, BP3K Landasan Ulin, dan BP3K Lingkar Selatan. Dalam penentuan apakah data-data curah hujan dari 3 stasiun tersebut mempunyai persamaan yang nyata maka harus dilakukan Uji Data Hujan. Uji Data Hujan yaitu menguji data hujan dengan memasangkan data-data hujan dari 2 stasiun hujan sehingga didapat 3 pasangan stasiun hujan (Lingkar Selatan-Landasan Ulin, Sungai Tabuk-Landasan Ulin, dan Lingkar Selatan-Sungai Tabuk). Untuk Perhitungan Uji Data Hujan pasangan Stasiun Hujan Lingkar Selatan-Sungai Tabuk adalah sebagai berikut: 
Untuk Pos Hujan Lingkar Selatan

Jumlah Sampel,N1 = 10

Nilai Rata-Rata, X- = $1696.3 \mathrm{~mm} /$ tahun

Deviasi Standar, $\mathrm{S} 1=$

| $\sum\left(\mathrm{Xi}_{-} \mathrm{X}^{-}\right) 2 /(\mathrm{N} 1-$

1) $\mid 0.5$

$=444.0 \mathrm{~mm} /$ tahun

Deviasi Standar Dari Perbedaan Rata-Rata

Hitung,

$\sigma 1-2=|\mathrm{S} 12 / \mathrm{N} 1+\mathrm{S} 22 / \mathrm{N} 2| 0.5$

$=\quad 498.9 \mathrm{~mm} /$ tahun

Variate Standar Normal Dari Distribusi Normal,

$$
\mathrm{t} \quad=\quad|(\mathrm{X}-1-\mathrm{X}-2) / \sigma 1-2|
$$$$
\mathrm{t} \quad=\quad-0.599
$$

Dengan Pengujiaan dua sisi, nilai variant dari standar normal (tc) pada derajat kepercayaan 5\% maka diperoleh tc $=1,734$. Oleh Karena nilai $\mathrm{t}=$ 0,599 maka hipotesis diterima. Dengan demikian dapat dikatakan $95 \%$ data hujan tersebut berasal dari populasi yang sama atau dikatakan $95 \%$ adalah benar bahwa data hujan kedua pos hujan Hujan
Untuk Pos Hujan Sungai Tabuk

$$
\begin{array}{lll}
\mathrm{N} 2 & = & 10 \\
\mathrm{X}- & = & 2364.8 \mathrm{~mm} / \text { tahun } \\
\mathrm{S} 2 & = & \left|\sum\left(\mathrm{Xi}-\mathrm{X}^{-}\right) 2 /(\mathrm{N} 2-1)\right| 0.5 \\
& =500.9 \mathrm{~mm} / \mathrm{tahun}
\end{array}
$$

Lingkar Selatan-Sungai Tabuk mempunyai persamaan yang nyata.Perhitungan Uji Data Hujan 2 pasangan Stasiun Hujan (Lingkar SelatanLandasan Ulin, Sungai Tabuk-Landasan Ulin) dikatakan 95\% adalah benar bahwa data hujan pos hujan Lingkar Selatan, Landasan Ulin dan Sungai Tabuk mempunyai persamaan yang nyata. Daerah penelitian tidak ada kemiringan lahan karena lahan didaerah tersebut relatif datar maka dalam menentukan curah hujan rata-rata dipakai dengan Cara Rerata Aljabar. Curah hujan rerata bulanan yang tercatat pada stasiun hujan tahun 2006-2015 diperlihatkan pada Tabel 2.a, Tabel 2.b.

Tabel 2.a . Curah Hujan Rerata Bulanan (Januari - Juni)

\begin{tabular}{|c|c|c|c|c|c|c|}
\hline \multirow{2}{*}{ Tahun } & \multicolumn{6}{|c|}{ Bulan } \\
\cline { 2 - 7 } & januari & februari & maret & april & mei & juni \\
\hline $\mathbf{2 0 0 6}$ & 430.8 & 352.2 & 245.4 & 248.0 & 95.2 & 158.5 \\
\hline $\mathbf{2 0 0 7}$ & 201.0 & 343.6 & 505.0 & 449.9 & 178.3 & 178.6 \\
\hline $\mathbf{2 0 0 8}$ & 216.1 & 182.3 & 410.9 & 210.8 & 62.2 & 76.5 \\
\hline $\mathbf{2 0 0 9}$ & 279.8 & 223.8 & 177.5 & 208.3 & 206.0 & 54.8 \\
\hline $\mathbf{2 0 1 0}$ & 279.3 & 299.5 & 423.8 & 355.2 & 197.2 & 194.3 \\
\hline $\mathbf{2 0 1 1}$ & 324.2 & 242.5 & 299.0 & 162.1 & 197.0 & 92.3 \\
\hline $\mathbf{2 0 1 2}$ & 247.1 & 253.3 & 224.2 & 197.4 & 77.2 & 64.7 \\
\hline $\mathbf{2 0 1 3}$ & 278.6 & 293.9 & 246.7 & 220.9 & 244.2 & 134.6 \\
\hline $\mathbf{2 0 1 4}$ & 273.9 & 223.2 & 283.1 & 183.9 & 286.0 & 222.5 \\
\hline $\mathbf{2 0 1 5}$ & 384.2 & 401.6 & 216.4 & 346.3 & 171.0 & 94.4 \\
\hline rata-rata & 291.5 & 281.6 & 303.2 & 258.3 & 171.4 & 127.1 \\
\hline Sumber :Analisis & & & & & \\
\end{tabular}

Tabel 2.b . Curah Hujan Rerata Bulanan (Juli - Desember) 


\begin{tabular}{|c|c|c|c|c|c|c|}
\hline \multirow{2}{*}{ Tahun } & \multicolumn{6}{|c|}{ Bulan } \\
\cline { 2 - 7 } & juli & agustus & september & oktober & november & desember \\
\hline $\mathbf{2 0 0 6}$ & 53.4 & 43.3 & 28.7 & 10.5 & 108.2 & 263.3 \\
\hline $\mathbf{2 0 0 7}$ & 189.1 & 78.6 & 28.9 & 103.9 & 275.2 & 306.3 \\
\hline $\mathbf{2 0 0 8}$ & 134.5 & 71.2 & 84.4 & 158.5 & 340.7 & 493.0 \\
\hline $\mathbf{2 0 0 9}$ & 36.2 & 45.3 & 17.8 & 159.7 & 384.8 & 214.2 \\
\hline $\mathbf{2 0 1 0}$ & 160.6 & 170.4 & 294.8 & 234.2 & 261.0 & 336.1 \\
\hline $\mathbf{2 0 1 1}$ & 74.3 & 42.0 & 58.8 & 139.3 & 146.0 & 611.8 \\
\hline $\mathbf{2 0 1 2}$ & 131.6 & 20.6 & 21.3 & 88.8 & 167.2 & 385.5 \\
\hline $\mathbf{2 0 1 3}$ & 140.3 & 74.0 & 51.5 & 80.0 & 290.6 & 331.9 \\
\hline $\mathbf{2 0 1 4}$ & 129.0 & 61.4 & 18.3 & 23.7 & 157.2 & 376.1 \\
\hline $\mathbf{2 0 1 5}$ & 52.7 & 32.5 & - & 15.8 & 79.5 & 255.8 \\
\hline rata-rata & 110.2 & 63.9 & 67.2 & 101.4 & 221.0 & 357.4 \\
\hline
\end{tabular}
Sumber :Analisis

Dari data di atas, curah hujan rata-rata di Kecamatan Sungai Tabuk adalah 196,2 mm. Curah hujan rata-rata tertinggi $357,4 \mathrm{~mm}$ pada bulan Desember dan Curah hujan rata-rata terendah 63,9 mm pada bulan Agustus. Pada daerah penelitian menggunakan perhitungan aljabar karena kondisi lahan di Kecamatan Sungai Tabuk, Landasan Ulin dan Lingkar Selatan merupakan lahan yang relatif datar.
Ketersediaan Air Dengan Metode Mock

Ketersediaan air atau Debit andalan didapat dengan memproses data curah hujan menjadi data debit. Dalam proses data curah hujan menjadi data debit. Perhitungan Metode Mock diperlihatkan pada Lampiran F (Perhitungan Metode Mock). Hasil debit andalan Metode Mock diperlihatkan pada Tabel 3. a, Tabel 3.b, dan Tabel 3.c.

Tabel 3.a. Hasil Debit Andalan (Data Debit: Metode Mock) Untuk Bulan Januari - April

Sumber : Analisis

\begin{tabular}{|c|c|c|c|c|c|}
\hline \multirow{2}{*}{ Peluang } & \multirow{2}{*}{ No. } & \multicolumn{4}{|c|}{ Bulan } \\
\hline & & Jan & $\mathrm{Peb}$ & Mar & Apr \\
\hline 0.091 & 1 & 11.412 & 12.915 & 15.064 & 13.222 \\
\hline 0.182 & 2 & 8.494 & 10.330 & 13.894 & 10.994 \\
\hline 0.273 & 3 & 8.108 & 8.981 & 13.148 & 10.008 \\
\hline 0.364 & 4 & 7.509 & 8.851 & 9.611 & 8.737 \\
\hline 0.455 & 5 & 6.156 & 8.839 & 9.020 & 8.172 \\
\hline 0.545 & 6 & 5.615 & 8.747 & 7.772 & 8.101 \\
\hline 0.636 & 7 & 5.418 & 8.545 & 7.373 & 6.789 \\
\hline 0.727 & 8 & 4.919 & 7.844 & 7.124 & 6.327 \\
\hline 0.818 & 9 & 4.321 & 7.257 & 6.053 & 5.818 \\
\hline 0.909 & 10 & 3.284 & 7.222 & 4.993 & 4.213 \\
\hline \multicolumn{2}{|c|}{ Debit Andalan $80 \%\left(\mathrm{~m}^{3} /\right.$ detik } & 4.441 & 7.374 & 6.267 & 5.920 \\
\hline \multicolumn{2}{|c|}{ Debit Andalan $85 \%\left(\mathrm{~m}^{3} /\right.$ detik } & 3.958 & 7.244 & 5.682 & 5.256 \\
\hline \multicolumn{2}{|c|}{ pebit Andalan 90\% $\left(\mathrm{m}^{3} /\right.$ detik } & 3.387 & 7.225 & 5.099 & 4.373 \\
\hline \multicolumn{2}{|c|}{ Debit Andalan 95\% (m $\mathrm{m}^{3} /$ detik } & 2.817 & 7.206 & 4.516 & 3.491 \\
\hline \multicolumn{2}{|c|}{ Debit Andalan 99\% ( $\mathrm{m}^{3} /$ detik } & 2.360 & 7.190 & 4.050 & 2.784 \\
\hline
\end{tabular}

Tabel 3.b .Hasil Debit Andalan (Data Debit :Metode Mock) Untuk Bulan Mei - Agustus 


\begin{tabular}{|c|c|c|c|c|c|}
\hline \multirow{2}{*}{ Peluang } & \multirow{2}{*}{ No. } & \multicolumn{4}{|c|}{ Bulan } \\
\cline { 3 - 6 } & & Mei & Jun & Jul & Agust \\
\hline 0.091 & 1 & 9.668 & 11.923 & 8.030 & 5.544 \\
\hline 0.182 & 2 & 7.604 & 11.105 & 7.083 & 3.754 \\
\hline 0.273 & 3 & 7.592 & 6.696 & 5.255 & 3.444 \\
\hline 0.364 & 4 & 6.681 & 6.622 & 4.872 & 2.491 \\
\hline 0.455 & 5 & 5.915 & 6.390 & 3.342 & 1.395 \\
\hline 0.545 & 6 & 5.293 & 5.171 & 2.928 & 1.082 \\
\hline 0.636 & 7 & 5.167 & 4.128 & 2.572 & 1.075 \\
\hline 0.727 & 8 & 4.947 & 3.566 & 2.500 & 1.074 \\
\hline 0.818 & 9 & 4.197 & 2.781 & 2.152 & 1.025 \\
\hline 0.909 & 10 & 4.085 & 2.364 & 1.875 & 0.782 \\
\hline Pebit Andalan $80 \%\left(\mathrm{~m}^{3} /\right.$ detik & 4.347 & 2.938 & 2.222 & 1.034 \\
\hline pebit Andalan $85 \%\left(\mathrm{~m}^{3} /\right.$ detik & 4.158 & 2.635 & 2.055 & 0.940 \\
\hline pebit Andalan $90 \%\left(\mathrm{~m}^{3} /\right.$ detik & 4.096 & 2.406 & 1.903 & 0.807 \\
\hline Debit Andalan $95 \%\left(\mathrm{~m}^{3} /\right.$ detik & 4.034 & 2.176 & 1.750 & 0.673 \\
\hline Debit Andalan $99 \%\left(\mathrm{~m}^{3} /\right.$ deti & 3.984 & 1.992 & 1.628 & 0.567 \\
\hline
\end{tabular}

Tabel 3.c .Hasil Debit Andalan (Data Debit :Metode Mock) Untuk Bulan September - Desember

\begin{tabular}{|c|c|c|c|c|c|}
\hline \multirow{2}{*}{ Peluang } & \multirow{2}{*}{ No. } & \multicolumn{4}{|c|}{ Bulan } \\
\cline { 3 - 6 } & & Sept & Okt & Nop & Des \\
\hline 0.091 & 1 & 7.868 & 5.820 & 9.546 & 20.462 \\
\hline 0.182 & 2 & 1.843 & 3.226 & 8.787 & 12.931 \\
\hline 0.273 & 3 & 1.615 & 2.831 & 7.622 & 9.710 \\
\hline 0.364 & 4 & 1.309 & 1.922 & 6.138 & 9.140 \\
\hline 0.455 & 5 & 1.288 & 1.693 & 5.635 & 9.036 \\
\hline 0.545 & 6 & 0.706 & 0.896 & 3.356 & 8.166 \\
\hline 0.636 & 7 & 0.558 & 0.775 & 2.938 & 7.630 \\
\hline 0.727 & 8 & 0.445 & 0.674 & 2.798 & 5.309 \\
\hline 0.818 & 9 & 0.331 & 0.139 & 1.602 & 5.000 \\
\hline 0.909 & 10 & 0.200 & 0.106 & 0.760 & 4.816 \\
\hline Debit Andalan $80 \%\left(\mathrm{~m}^{3} / \mathrm{deti}\right.$ & 0.354 & 0.246 & 1.841 & 5.062 \\
\hline Debit Andalan $85 \%\left(\mathrm{~m}^{3} / \mathrm{det}\right.$ & 0.285 & 0.128 & 1.307 & 4.936 \\
\hline Debit Andalan $90 \%\left(\mathrm{~m}^{3} / \mathrm{det}\right.$ & 0.213 & 0.110 & 0.844 & 4.835 \\
\hline Debit Andalan $95 \%\left(\mathrm{~m}^{3} / \mathrm{det}\right.$ & 0.141 & 0.091 & 0.381 & 4.734 \\
\hline Debit Andalan $99 \%\left(\mathrm{~m}^{3} / \mathrm{deti}\right.$ & 0.084 & 0.077 & 0.010 & 4.653 \\
\hline
\end{tabular}

Sumber :Analisis 


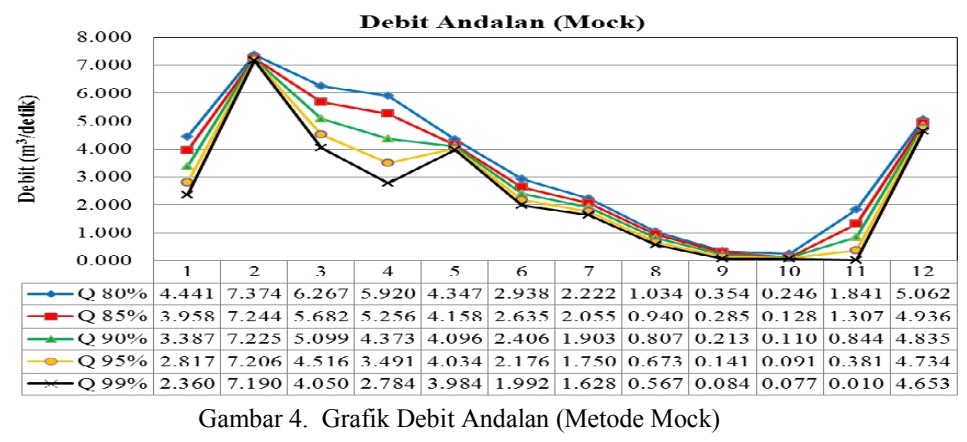

Pada grafik debit andalan 80\% (ketersediaan air irigasi) didapat rata - rata debit andalan $80 \%$ adalah $3,504 \mathrm{~m} 3$ / detik dengan debit andalan $80 \%$ tertinggi tedapat pada bulan februari yaitu $7,37 \mathrm{~m} 3 /$ detik dan debit $80 \%$ nya didapat $0,24 \mathrm{~m} 3 /$ detik. Sedangkan kebutuhan air disawah untuk tanaman padi dan palawija dapat dilihat pada Tabel 3.d, 3.e, 3.f, dan 3.g. debit terendah berada pada bulan oktober yang

Tabel 3.d Kebutuhan air di sawah untuk padi

\begin{tabular}{|c|c|c|c|c|c|c|c|c|c|c|c|c|c|}
\hline \multirow{3}{*}{ Pola Tanam } & \multirow{3}{*}{ Awal } & \multicolumn{6}{|c|}{ Kebutuhan Air Di Sawah Untuk Padi } & \multicolumn{6}{|c|}{ Kebutuhan Air Di Sawah Untuk Padi } \\
\hline & & \multicolumn{2}{|c|}{ Januari } & \multicolumn{2}{|c|}{ Februari } & \multicolumn{2}{|c|}{ Maret } & \multicolumn{2}{|c|}{ April } & \multicolumn{2}{|c|}{ Mei } & \multicolumn{2}{|c|}{ Juni } \\
\hline & & I & II & $\mathrm{I}$ & II & I & II & $\mathrm{I}$ & II & I & II & I & II \\
\hline \multirow{4}{*}{$\begin{array}{l}\text { Padi Biasa- } \\
\text { Padi Biasa }\end{array}$} & Nopember II & 3,819 & 4,693 & 10,098 & 6,036 & 5,592 & 3,913 & 0,000 & 0,000 & 0,007 & 0,007 & 0,008 & 0,007 \\
\hline & Desember I & 6,923 & 4,693 & 8,240 & 8,049 & 6,008 & 9,434 & 1,194 & 1,729 & 0,198 & 0,007 & 0,008 & 0,008 \\
\hline & Desember II & 6,986 & 7,728 & 8,240 & 6,191 & 8,005 & 9,933 & 6,001 & 3,340 & 3,010 & 0,164 & 0,008 & 0,008 \\
\hline & Januari I & 6,986 & 7,728 & 10,195 & 6,191 & 6,147 & 11,957 & 6,403 & 8,279 & 4,144 & 3,168 & 0,208 & 0,008 \\
\hline
\end{tabular}

Sumber :Analisis

Tabel 3.e. Kebutuhan air di sawah untuk padi

\begin{tabular}{|c|c|c|c|c|c|c|c|c|c|c|c|c|c|c|}
\hline \multirow{3}{*}{ Pola Tanam } & \multirow{3}{*}{ Awal } & \multicolumn{6}{|c|}{ Kebutuhan Air Di Sars ah Untuk Padi } & \multicolumn{6}{|c|}{ Kebutuhan Air DiSawah Untuk Padi } & \multirow{3}{*}{ Rata-Rata } \\
\hline & & \multicolumn{2}{|c|}{ Juli } & \multicolumn{2}{|c|}{ Agustus } & \multicolumn{2}{|c|}{ September } & \multicolumn{2}{|c|}{ Oktober } & \multicolumn{2}{|c|}{ Nor ember } & \multicolumn{2}{|c|}{ Desember } & \\
\hline & & I & II & I & II & I & II & I & II & I & II & I & II & \\
\hline Padi Biasar & Nopember II & 0,006 & 0,008 & 0,000 & 0,008 & 0,005 & 0,003 & 0,002 & 0,000 & 0,000 & 13,591 & 9,782 & 8,249 & 2,743 \\
\hline \multirow[t]{3}{*}{ Padi Biasa } & Desember I & 0,006 & 0,007 & 0,010 & 0,009 & 0,007 & 0,004 & 0,004 & 0,001 & 0,000 & 0,000 & 9,782 & 8,249 & 2,690 \\
\hline & Desember II & 0,008 & 0,007 & 0,009 & 0,010 & 0,008 & 0,007 & 0,005 & 0,003 & 0,000 & 0,000 & 0,000 & 8,249 & 2880 \\
\hline & JanuariI & 0,008 & 0,009 & 0,000 & 0,009 & 0,009 & 0,007 & 0,007 & 0,004 & 0,002 & 0,000 & 0,000 & 0,000 & 2,978 \\
\hline
\end{tabular}

Sumber: Analisis

Tabel 3.f. Kebutuhan air di sawah untuk palawija 


\begin{tabular}{|c|c|c|c|c|c|c|c|c|c|c|c|c|c|}
\hline \multirow{3}{*}{ Pola Tanam } & \multirow{3}{*}{$\begin{array}{l}\text { Atid } \\
\text { Tamm }\end{array}$} & \multicolumn{6}{|c|}{ Kehutuhan AirDiSanah Untul Palanija } & \multicolumn{6}{|c|}{ Kebutuhan AirDi Sawah Untul Pala wija } \\
\hline & & \multicolumn{2}{|c|}{ Januari } & \multicolumn{2}{|c|}{ Februari } & \multicolumn{2}{|c|}{ Maret } & \multicolumn{2}{|c|}{ April } & \multicolumn{2}{|c|}{ Mei } & \multicolumn{2}{|c|}{ Juni } \\
\hline & & $\mathrm{I}$ & II & $\mathrm{I}$ & II & $\mathrm{I}$ & II & $\mathrm{I}$ & II & $\mathrm{I}$ & II & $\mathrm{I}$ & II \\
\hline \multirow[t]{4}{*}{ Palawja I-Pahnija II } & NopenberII & 0,08 & 0,014 & 0,032 & 0,025 & 0,030 & 0,015 & 0,015 & 0,010 & $0,0,04$ & 0,005 & $0,0,00$ & 0,050 \\
\hline & Des emberI & 0,042 & $0,0,03$ & 0,012 & 0,026 & 0,030 & 0,037 & 0,017 & 0,017 & $0,0,04$ & 0,005 & $0,0,00$ & 0,020 \\
\hline & Des emberII & 0,042 & $0,0,43$ & 0,05 & 0,009 & 0,05 & 0,038 & 0,028 & 0,019 & 0,014 & 0,006 & 0,020 & 0,020 \\
\hline & Januail & 0,42 & $0,0,43$ & 0,005 & 0,0003 & 0,009 & 0,033 & 0,099 & $0,0,29$ & 0,016 & 0,016 & $0,0,21$ & 0,020 \\
\hline
\end{tabular}

Sumber: Analisis

Tabel 3.g. Kebutuhan air di sawah untuk palawija

\begin{tabular}{|c|c|c|c|c|c|c|c|c|c|c|c|c|c|c|}
\hline \multirow{3}{*}{ Pola Tanam } & \multirow{3}{*}{$\begin{array}{l}\text { Aval } \\
\text { Tanum }\end{array}$} & \multicolumn{6}{|c|}{ Kebutruan _tirDiSavahLuntuk Palawija } & \multicolumn{6}{|c|}{ Keburtuhan AirDiSavah Untuk Palauija } & \multirow{3}{*}{ Rata-Rata } \\
\hline & & \multicolumn{2}{|c|}{ Juli } & \multicolumn{2}{|c|}{ Agustus } & \multicolumn{2}{|c|}{ September } & \multicolumn{2}{|c|}{ Oktober } & \multicolumn{2}{|c|}{ Norember } & \multicolumn{2}{|c|}{ Desember } & \\
\hline & & I & II & I & II & I & II & $\mathrm{I}$ & II & $\mathrm{I}$ & II & $\mathrm{I}$ & II & \\
\hline Phaйі I-Phavija II & NopenterII & 0,02 & 0,063 & 0,032 & 0,042 & 0,044 & 0,044 & 0,032 & 0,020 & 0,002 & 0,054 & 0,051 & 0,048 & 0,030 \\
\hline & DesentherI & 0,052 & 0,653 & 0,064 & 0,033 & 0,038 & 0,043 & 0,035 & 0,031 & 0,008 & 0,004 & 0,051 & 0,048 & 0,029 \\
\hline & DesentherII & 0,023 & 0,653 & 0,064 & 0,064 & 0,131 & 0,038 & 0,034 & 0,034 & 0,021 & 0,010 & 0,002 & 0,048 & 0,029 \\
\hline & Janui I & 0,03 & 0,024 & 0,064 & 0,064 & 0,060 & 0,031 & 0,028 & 0,033 & 0,024 & 0,025 & 0,008 & 0,001 & 0,029 \\
\hline
\end{tabular}

Dari hasil Analisa diatas didapat kebutuhan air rata-rata adalah 2,690 m3/detik dimana awal tanam desember I dengan menggunakan pola tanam padi biasa-padi biasa, sedangkan kebutuhan air untuk palawija rata-rata adalah $0,029 \mathrm{~m} 3 /$ detik. Dari hasil analisa didapat ketersediaan air saluran irigasi Sungai Tabuk (nilai rata-rata 3,504 m3/detik) bisa memenuhi kebutuhan air irigasi (nilai rata-rata 2,690 $+0,029=$ $2,719 \mathrm{~m} 3 /$ detik).

\section{KESIMPULAN}

Berdasarkan data bangkitan hujan dan evapotranspirasi (metode Mock ) didapat pada sistem irigasi wilayah Sungai Tabuk debit rata rata pertahun adalah 5,758 $\mathrm{m} 3$ / detik. Dengan debit tertinggi terjadi pada bulan Maret yaitu 9,405m3/ detik dan debit terendah berada pada bulan September sebesar 1,616 m3 / detik.

Debit andalan $80 \%$ didapat rata - rata adalah $3,504 \mathrm{~m} 3 /$ detik dengan debit andalan $80 \%$ tertinggi tedapat pada bulan Februari yaitu 7,37 m3/ detik dan debit terendah berada pada bulan Oktober yang debit $80 \%$ nya didapat $0,24 \mathrm{~m} 3 /$ detik.

Kebutuhan air rata-rata adalah 2,690 m3/detik dimana awal tanam desember I dengan menggunakan pola tanam padi biasa-padi biasa, sedangkan kebutuhan air untuk palawija rata-rata adalah $0,029 \mathrm{~m} 3 /$ detik, sehingga total kebutuhan rata-rata air saluran irigasi adalah 2,719 m3/detik. Dari hasil analisa didapat ketersediaan rata-rata air saluran irigasi Sungai Tabuk dapat memenuhi kebutuhan rata-rata air irigasinya.

\section{REFERENSI}

Agoes, Herliyani Farial;Fakhrurrazi;Muhlis, Adriani, 2014.Analisi Keseimbangan Air Daerah Aliran Sungai Tabanio Kabupaten Tanah Laut. Jurnal INTEKNA ISSN: 1412 5609 Tahun XIV No. 2 Nopember 2014

I Made Karniana .2011. Perhitungan Debit Rencana Bangunan Air. Graha ilmu. Yogyakarta

Sudirman, diding 1999. Penerapan Metode Mock Untuk Menghitung Debit Andalan Di Sub Daerah Pengaliran Sungai Citarum Hulu. ITB. Bandung

Viralsia Ivana Kundimang, Liani A. H., Eveline M.W. (2015, Desember ). Analisis Ketersediaan Air Sungai Talawaan untuk kebutuhan Irigasi di Daerah Irigasi 
Talawaan Meras dan Talawaan Atas. tekno voume 13 no. 64

Wurjanto A, Sudirman D. Modul Perhitungan Debit Andalan Sungai. ITB . Bandung 